\title{
Research on Vertical distribution and settling process of Cd in Jiaozhou
}

\author{
bay \\ Dongfang Yang ${ }^{1,2,3, a}$, Fengyou Wang ${ }^{1,2}$, Zhaohui Sun ${ }^{1,2}$, \\ Xiaoli Zhao ${ }^{1,2}$ and Sixi Zhu ${ }^{1,2}$ \\ ${ }^{1}$ Research Center for Karst Wetland Ecology, Guizhou Minzu University, Guizhou Guiyang, \\ Guizhou Guiyang, China; \\ ${ }^{2}$ College of Chemistry and Environmental Science, Guizhou Minzu University, Shanghai, 550025, \\ China; \\ ${ }^{3}$ North China Sea Environmental Monitoring Center, SOA, Qingdao 266033, China. \\ adfyang_dfyang@126.com; 'borresponding author; 'wangfy2001@yahoo.com.cn.
}

Keywords: Cd; Vertical; Horizontal; Seasonal; Distribution; Settling process; Jiaozhou Bay

Abstract. Based on the investigation data on Cd in Jiaozhou Bay in May, September and October in 1983, were analyzed the horizontal and seasonal distribution, vertical variation and variation range of $\mathrm{Pb}$, revealed the seasonal variation process, settling process and water's effect of Cd. Results showed that $\mathrm{Cd}$ contents in both surface and bottom waters were in orders of spring > summer > autumn. Pollution sources of $\mathrm{Cd}$, particularly river flow determined the variations of $\mathrm{Cd}$ in surface waters, as well as in bottom waters.In the waters in the bay mouth in May, September and October, in temporal, spatial, variation, horizontal, and regional scales, the following laws were revealed. As the time change, the variations of $\mathrm{Cd}$ in surface and bottom waters were consistent. There were both consistence and contrary of the horizontal variations of $\mathrm{Cd}$ in surface and bottom waters. The variation ranges of $\mathrm{Cd}$ in surface and bottom waters were basically the same. $\mathrm{Cd}$ was tending to be homogeneous in surface and botom waters. The analysis revealed the reapd settling process of $\mathrm{Cd}$, the rapid settling and accumulation effect of $\mathrm{Cd}$, the rapid and continous settlement of $\mathrm{Cd}$, vertical water's effect of $\mathrm{Cd}$, the processes of river flow discharging and than the settling of $\mathrm{Cd}$.

\section{Introduction}

$\mathrm{Cd}$ is one of the cristal heavy metal that generated from industrial and agricultural production. A large amount of Cd-contained wasterwater, wastegas and wasteresidue had been generating along with the rapid increasing of industry and agriculture, yet the wastewater treatment was always lagging. Hence, Cd pollution has been one of the serious environmental issues. Ocean is the sink of various pollutants, and the Cd pollution in the ocean particully in coastal waters are sesious in many marine countries and regions [1-5]. Hence, understanding the transfer processes of $\mathrm{Cd}$ in marine waters is essential to pollution protection. Based on investigation data on $\mathrm{Cd}$ in waters in Jiaozhou Bay in 1983, eastern China, this paper analyzed the horizontal and seasonal distribution, vertical variation and variation range of $\mathrm{Pb}$, revealed the seasonal variation process, settling process and water's effect of $\mathrm{Cd}$, and to provide basis for pollution control and environmental remediation of Cd. 


\section{Materials and method}

Jiaozhou Bay $\left(35^{\circ} 55^{\prime}-36^{\circ} 18^{\prime} \mathrm{N}, 120^{\circ} 04^{\prime}-120^{\circ} 23^{\prime} \mathrm{E}\right)$ is located in Shandong Province, eastern China. Cities of Qingdao, Jiaozhou and Jiaonan are surrounding the bay, and the bay mouth is connected to the Yellow Sea in the south (Fig. 1). The size of the bay is $446 \mathrm{~km}^{2}$, yet the width of the bay mouth is only $2.5 \mathrm{~km}$. This semi-closed bay has more than ten inflow rivers, inculding Dagu River, Haibo River, Licun River and Loushan River etc., most of which are seasonal rivers whose hydrological characteristics are mainly impacted by rainfall [6-7].

The data was provided by North China Sea Environmental Monitoring Center. The survey was conducted in May, September and October 1983. Surface and bottom water samples in five sampling sites (H34, H35, H36, H37 and H82) were collected and measured followed by National Specification for Marine Monitoring [5].

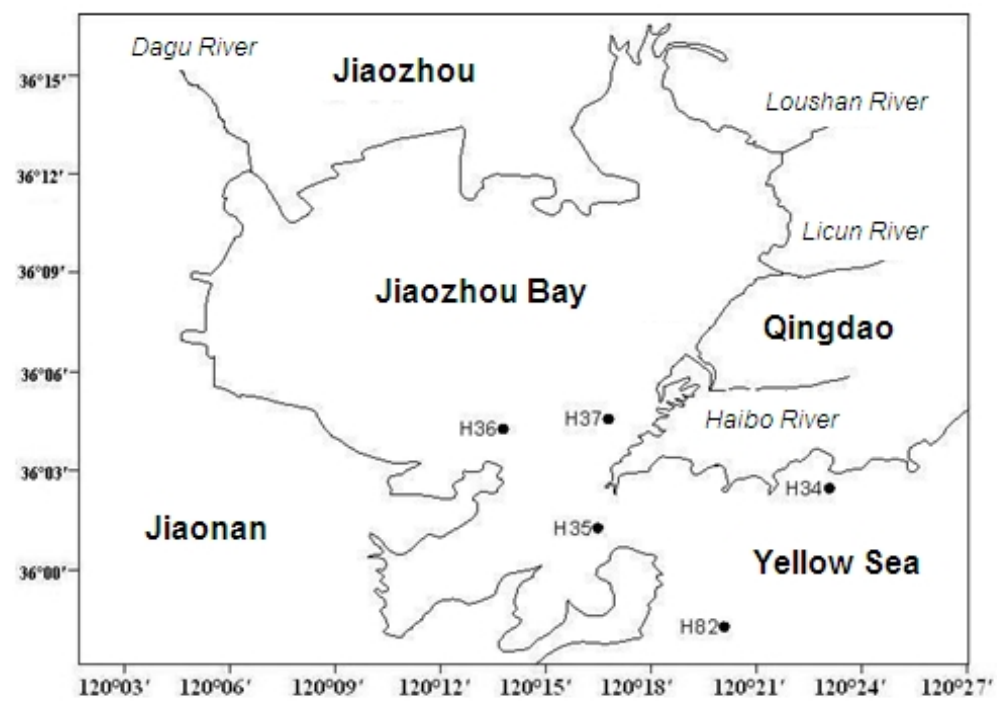

Fig. 1 Geographic location and sampling sites of Jiaozhou Bay

\section{Results}

Seasonal variations of $\mathbf{C d}$. Cd contents in surface waters in May, September and October 1983 were ranged from 0.09-0.41 $\mu \mathrm{g} \mathrm{L}^{-1}, 0.40-3.33 \mu \mathrm{g} \mathrm{L}^{-1}$ and $0.10-1.50 \mu \mathrm{g} \mathrm{L}{ }^{-1}$, respectively. The seasons in May, September and October are spring, summer and autumn, respectively. Hence, Cd contents in surface water in different seasons were in orders of spring > summer > autumn. Meanwhile, Cd contents in bottom waters in May, September and October 1983 were ranged from $0.10-0.15 \mu \mathrm{g} \mathrm{L}^{-1}$, 0.67-2.00 $\mu \mathrm{g} \mathrm{L}^{-1}$ and 0.03-2.00 $\mu \mathrm{g} \mathrm{L}^{-1}$, respectively. Cd contents in surface water in different seasons were also in orders of spring > summer $>$ autumn. Meanwhile, in according to the ranges of Cd contents in both surface and bottom waters, we found that these were positive relationships between $\mathrm{Cd}$ contents in surface waters and which in bottom waters. That was, the higher $\mathrm{Cd}$ contents in surface waters, the higher the Cd contents in bottom waters, the reverse was also true.

Hozizontal distributions of $\mathbf{C d}$. In May, $\mathrm{Cd}$ contents in surface waters were showing gradient

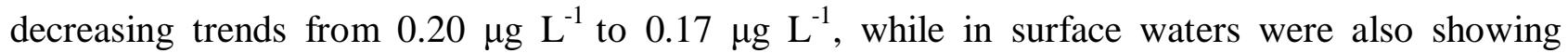
gradient decreasing trends from $0.15 \mu \mathrm{g} \mathrm{L}^{-1}$ to $0.14 \mu \mathrm{g} \mathrm{\textrm {L } ^ { - 1 }}$. Cd contents in both surface and bottom waters were decreasing from $\mathrm{H} 37$ in coastal waters in the east of the bay mouth to $\mathrm{H} 35$ in the bay 
mouth. In September, $\mathrm{Cd}$ contents in surface waters were showing gradient increasing trends from $1.10 \mu \mathrm{g} \mathrm{L}^{-1}$ to $2.00 \mu \mathrm{g} \mathrm{L}^{-1}$, while in surface waters were also showing gradient increasing trends from $1.17 \mu \mathrm{g} \mathrm{L}^{-1}$ to $1.63 \mu \mathrm{g} \mathrm{L}{ }^{-1}$. Cd contents in both surface and bottom waters were increasing from $\mathrm{H} 37$ in coastal waters in the east of the bay mouth to H35in the bay mouth. In October, Cd contents in surface waters were showing gradient decreasing trends from $1.50 \mu \mathrm{g} \mathrm{L}^{-1}$ to $0.50 \mu \mathrm{g} \mathrm{L} \mathrm{L}^{-1}$, while in surface waters were also showing gradient increasing trends from $1.50 \mu \mathrm{g} \mathrm{L}^{-1}$ to $2.00 \mu \mathrm{g} \mathrm{L}^{-1}$. Cd contents in surface waters were decreasing from $\mathrm{H} 37$ in coastal waters in the east of the bay mouth to H35in the bay mouth, while in bottom waters were reverse.

Vertical variations of $\mathbf{C d}$. In order to reveal the vertical variations of $\mathrm{Cd}$, the contents in surface waters in the fiver sampling sites in May, September and October 1983 were subtracted from which in bottom waters, and the results were list in Table 1. For the whole year, the subtraction of $\mathrm{Cd}$ contents in surface from which in bottom waters ranged from -1.50-2.53 $\mu \mathrm{g} \mathrm{L}^{-1}$, indicated that $\mathrm{Cd}$ contents in surface and bottom waters were very closed. In May, the differences ranged from -0.01-0.30 $\mu \mathrm{g} \mathrm{L}^{-1}$. Except in Site H82 was negative, the subtractions in the other four sampling sites were positive. In September, the differences ranged from $-1.50-2.53 \mu \mathrm{g} \mathrm{L}{ }^{-1}$. The subtractions in Site $\mathrm{H} 35$ and $\mathrm{H} 36$ were positive, while in other sampling sites were negative. In October, the differences ranged from -1.50-0.70 $\mu \mathrm{g} \mathrm{L}^{-1}$. The subtractions in Site H35 and H37 were zero, in Site H35 and H34 were negative, and in Site H82 was positive.

Table 1 Results of subtracting Cd contents in surface waters from which in bottoms in the five sampling sites in May, September and October 1983

\begin{tabular}{cccccc}
\hline Month & H35 & H34 & H36 & H37 & H82 \\
\hline May & Positive & Positive & Positive & Positive & Negative \\
September & Positive & Negative & Positive & Negative & Negative \\
October & Negative & Negative & Zero & Zero & Positive \\
\hline
\end{tabular}

\section{Discussion}

Seasonal variations process of $\mathbf{C d}$. For seasonal variation, $\mathrm{Cd}$ contents in surface waters in different seasons were in orders of spring > summer > autumn. That was $\mathrm{Cd}$ contents were begining to increase from the lowest value $\left(0.41 \mu \mathrm{g} \mathrm{L}^{-1}\right)$ in May, and then reaching the highest value $(3.33 \mu \mathrm{g}$ $\left.\mathrm{L}^{-1}\right)$ in summer, and finally decreasing to moderate value $\left(1.50 \mu \mathrm{g} \mathrm{L}^{-1}\right)$ in autumn. In according to the horizontal distributions, the major sources of $\mathrm{Cd}$ were stream flow, marine terminals, overland flow from the islands heads, and overland flow, which were determing the horizontal distributions of $\mathrm{Cd}$ in surface waters. Meanwhle, under the vertical water's effect [9], the variation of $\mathrm{Cd}$ in surface waters were determing the horizontal distributons of $\mathrm{Cd}$ in bottom waters.

Settling process of $\mathbf{C d}$. By means of the vertical water's effect [9], Cd contents in waters were changing a lot after passing through the water body. Tn summer, tha activities of zooplankton and phytoplankton were increasing, which were able to enhencing the adsorption capacity of suspended particulate matters due to the large production of colloid. Hence, a large amount of Cd was absorbed and was settling to the sea bottom under the force of gravity and current [2]. That was the horizontal settling process of $\mathrm{Pb}$. 
The settling process of $\mathrm{Pb}$ could be verified by its seasonal variations. $\mathrm{Cd}$ contents in both surface and bottom waters in different seasons were in orders of spring $>$ summer $>$ autumn. The reason was that $\mathrm{Cd}$ in surface waters was absorbed and was settling to the sea bottom under the force of gravity and current.

The settling process of $\mathrm{Pb}$ could also be verified by its horizontal distributions. In May and September, the horizontal distributions of $\mathrm{Pb}$ in surface and bottom waters were consistent, the reason was that both $\mathrm{Cd}$ contents in surface waters and the settling strength were strong enough to matain same horizontal distribution trends in spring and summer. However, the horizontal distributions of $\mathrm{Pb}$ in surface and bottom waters were consistent in October, because the source strengths of $\mathrm{Pb}$ were decreasing in autumn, yet the settling of $\mathrm{Pb}$ was continous, and the accumulation of $\mathrm{Pb}$ in bottom waters was also continous. Both seasonal variations, vertical variations and horizontal distributions were showeing the settling process of $\mathrm{Cd}$ in waters.

In variation scale, the variation ranges of Cd contents in the waters in the bay mouth in surface and bottom waters were basically the same in May, September and October. In generally, the higher Cd contents in surface waters, the higher Cd contents in bottom waters. That was showing the rapid and continous settlement of $\mathrm{Cd}$, and leading to the consistency of $\mathrm{Cd}$ contents in surface and bottom waters.

In vertical scale, the subtraction of Cd contents in surface from which in bottom waters in May ranged from $-0.01-0.30 \mu \mathrm{g} \mathrm{L}^{-1}$, indicated that $\mathrm{Cd}$ contents in surface and bottom waters were very closed. The subtraction of $\mathrm{Cd}$ contents in surface from which in bottom waters in May ranged from $-1.50-2.53 \mu \mathrm{g} \mathrm{L} \mathrm{L}^{-1}$, indicated that the differences of Cd contents in surface and bottom waters were very big if $\mathrm{Cd}$ contents in both surface and bottom waters were very high. In October, subtraction of $\mathrm{Cd}$ contents in surface from which in bottom waters ranged from -1.50-0.70 $\mu \mathrm{g} \mathrm{L}^{-1}$, indicated that the differences of $\mathrm{Cd}$ contents in surface and bottom waters were very small if $\mathrm{Cd}$ contents in both surface and bottom waters were very low. As a whole, $\mathrm{Cd}$ contents in surface and bottom waters were very closed in May, September and October. It could be found that Cd could be settling to the bottom waters rapidly, and were lossing only a few under the vertical water's effect [9].

In regional scace, in waters in the bay mouth, the subtrations of Cd contents in surface waters from which in bottom waters were also changing along with time. These differences were indicating the variations of $\mathrm{Cd}$ contents in surface and bottom waters. Once $\mathrm{Cd}$ was discharged the the bay from river flow, it was firstly reaching the surface wates, and than was settling to the bottom waters rapidly and continously, and was showing the variations of $\mathrm{Cd}$ contents in surface and bottom waters.

In May, Cd contents in surface waters in most of the sampling sites were higher than that in bottom waters except one site in the south of the outer bay. The reason was that the the source strengths of $\mathrm{Cd}$ were increasing in wet season, and a large amount of $\mathrm{Cd}$ was discharged to the bay by river flow. Hence, Cd contents in surface waters in most of the regions in the bay were higher than that in bottom waters. Cd contents in surface waters in the site in the south of the outer bay were lower than that in bottom waters, the reason was that $\mathrm{Cd}$ from the sources had not reached that position. 
In September, $\mathrm{Cd}$ contents in surface waters in regions in the bay mouth and the southwest inside the bay were higher than that in bottom waters, and were reverse in regions in the northwest and outer bay. The reason was that the the source strengths of Cd were decreasing in September, and the source strengths were only able to make enouth effects in in regions in the bay mouth and the southwest inside the bay. While for regions in the northwest and outer bay, the source strengths of $\mathrm{Cd}$ was very weak, and $\mathrm{Cd}$ contents in surface waters were lower than that in bottom waters due to the continous settlement via vertical water's effect [9].

In October, Cd contents in surface waters in the site in the south of the outer bay were higher than that in bottom waters, while in the bay mouth and the north of the outer bay were reverse. Meanwhile, in waters inside the bay mouth, Cd contents in surface and bottom waters were no different. The reason was that the $\mathrm{Cd}$ inputs from river flow were stop in October, and due to the homogeneity of waters, $\mathrm{Cd}$ contents in surface and bottom waters inside the bay mouth were also homogeneity. In waters of the south of the outer bay, however, $\mathrm{Cd}$ contents were very low, and the settlement of Cd was very little.

In May, a large amount of $\mathrm{Cd}$ was discharged to the bay due to the plenty of rainfall-runoff. In September, the source strength of $\mathrm{Cd}$ from river flow was decreasing. In October, Cd inputs from river flow were stop. We could see the horizontal transfer process and vertical settling process of $\mathrm{Cd}$ in waters was a process of $\mathrm{Cd}$ was inputting from river flow and then was settling to the sea bottom. Hence, the variation process of $\mathrm{Cd}$ in waters was that, $\mathrm{Cd}$ contentswere high in surface waters in May, $\mathrm{Cd}$ contents in bottom waters were high in bottom waters in September, and $\mathrm{Cd}$ contents were no different in surface and bottom waters in October.

\section{Conclusion}

Cd contents in both surface and bottom waters were in orders of spring > summer > autumn. Pollution sources of $\mathrm{Cd}$, particularly river flow determined the variations of $\mathrm{Cd}$ in surface waters, as well as in bottom waters.

In temporal scale, in the waters in the bay mouth, in May, September and October, in according to the seasonal variations, the variations of $\mathrm{Cd}$ conents in surface and bottom waters were consist. The rapid and continous settlement of $\mathrm{Cd}$ were showing in any time-process.

In vertical scale, in May and September, the horizontal distributions of $\mathrm{Pb}$ in surface and bottom waters were consistent, while the horizontal distributions of $\mathrm{Pb}$ in surface and bottom waters were consistent in October. As the time change, the consistency and contrary of the variation of $\mathrm{Cd}$ in surface and bottom waters were revealing the rapid and continous settlement of $\mathrm{Cd}$.

In variation scale, the variation ranges of Cd contents in the waters in the bay mouth in surface and bottom waters were basically the same in May, September and October. That was showing the rapid and continous settlement of $\mathrm{Cd}$. 
In vertical scale, $\mathrm{Cd}$ contents in surface and bottom waters were very closed in May, September and October. It could be found that $\mathrm{Cd}$ could be settling to the bottom waters rapidly, and were lossing only a few under the vertical water's effect.

In regional scace, $\mathrm{Cd}$ contents were high in surface waters in May, $\mathrm{Cd}$ contents in bottom waters were high in bottom waters in September, and Cd contents were no different in surface and bottom waters in October. This indicated tht process of $\mathrm{Cd}$ was inputting from river flow and then was settling to the sea bottom.

The horizontal transfer process and vertical settling process of $\mathrm{Cd}$ in waters was revealed by the horizontal distributions and seasonal variations of $\mathrm{Cd}$. Based on the research on $\mathrm{Cd}$ in Jiaozhou Bay waters, we defined the transfer processes of Cd in waters, and the vertical water's effect on $\mathrm{Cd}$.

\section{Acknowledgement}

This research was sponsored by Doctoral Degree Construction Library of Guizhou Nationalities University, Education Ministry's New Century Excellent Talents Supporting Plan (NCET-12-0659), Project of Outstanding Technological Educators of Governor of Guizhou ([2012]71), Project of Low Carbon Technology Plan of Guiyang (2012205]), Project of Science and Technology Foundation of Guiyang (LKM[2012]05), Special Research Projects of High Level Talents of Guizhou Province (TZJF-2011- 44), the China National Natural Science Foundation (31560107) and Research Projects of Guizhou Nationalities University ([2014]02).

\section{Reference}

[1] Yang DF, Chen Y, Wang H, et al.: Coastal Engineering, Vol. 29 (2010), p. 73-82. (in Chinese)

[2] Yang DF, Chen Y, Chang YX, et al.: Coastal Engineering, Vol. 32(2013), p. 68-78. (in Chinese)

[3] Yang DF, Zhu SX, Wang FY, et al.: Applied Mechanics and Materials, Vols.644-650 (2014), p. 5325-5328.

[4] Yang DF, Wang FY, Wu YF et al.: Applied Mechanics and Materials, Vols.644-650 (2014), p. 5329-5312.

[5] Yang DF, Cheng ST, Li BL, et al.:Proceedings of the 2015 international symposium on computers and informatics, (20150, p. 2667-2674.

[6] Yang DF, Chen Y, Gao ZH, et al.: Chinese Journal of Oceanology and Limnology, Vol. 23 (2005), pp. 72-90.

[7] Yang DF, Wang F, Gao ZH, et al.: Maine Science, Vol. 28(2004): 71-74. (in Chinese with English abstract)

[8] State Ocean Administration. The specification for marine monitoring: Beijing, Ocean Precess, (1991).

[9] Yang DF, Wang FY, He HZ, et al.:Proceedings of the 2015 international symposium on computers and informatics, (2015), p. 2655-2660.

[10] Yang DF, Ding ZR, Zheng L, et al.: Coastal Enginering, Vol. 30(2011): 66-74. 